\title{
Olfactory Neurocytoma
}

National Cancer Institute

\section{Source}

National Cancer Institute. Olfactory Neurocytoma. NCI Thesaurus. Code C67156.

A rare benign neuroectodermal tumor originating from olfactory receptor cells in the nasal cavity. Microscopically, it is characterized by the absence of malignant characteristics and the absence of rosettes formation. 